\title{
Fluctuations of Flats' Prices in Poznań During 1999-2008
}

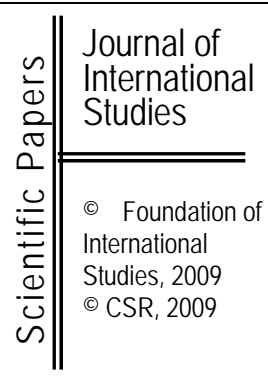

Radosław Trojanek

Departament of Investment and Real Estate

Poznañ University of Economics

e-mail:r.trojanek@ue.poznan.pl

\begin{abstract}
The main aim of the paper is to identify price fluctuations on the secondary housing market in the years 1996-2008 in Poznań. The paper is divided into three parts. In the first part the time series components are analyzed. Then the methods of business cycles analysis are applied to house prices fluctuations on the local markets. The third part of the paper contains analysis of fluctuation of flats' prices in Poznań in the years 1996-2008.
\end{abstract} Submitted: January, 2009 $1^{\text {st }}$ revision: March, 2009 Accepted: June, 2009

Keywords: residential market, house price fluctuations

JEL classification: E32, L16, P1

\section{Introduction}

The subject scope results from the aim of the paper and includes price fluctuations on the secondary housing market, involving both property rights and cooperative property rights for private accommodation. In this research only dwellings located in multifamily buildings are analyzed.

The choice depends on two factors. Firstly, majority of dwellings are located just in multifamily buildings (blocks of flats - up to $90 \%$ in big Polish cities). Secondly, houses are characterized by a great differentiation regarding both quantitative and qualitative features, which requires that the data base should involve the appropriate information about each property in order to construct house price indexes. On the other hand the secondary housing market is greater than the primary market (approximately up to three times) taking into consideration the number of transactions.

\section{Time series' components}

Empirical analyses the aim of which is to differentiate and characterize the changes occurring in macroeconomic variables are based on the assumption that the following elements may be distinguished in the structure of a time series ${ }^{1}$ :

$\square$ trend component,

$\square$ seasonal component,

$\square$ cyclical component,

$\square$ irregular component.

\footnotetext{
${ }^{1}$ M.K. Evans, Practical Business Forecasting, Blackwell Publishing, Oxford 2003, p. 205.
} 
Trend is a long-time regular direction of changes (increase or decrease) of the value of examined variable. Trend can be used for object illustration of growth trend and facilitates retrospective description of examined factor in time ${ }^{2}$. Trend is a result of operation of certain set of factors both objective and subjective ones, affecting examined variable.

Seasonal fluctuations are changes of intensity of economic activity that occur in one year time and which are the result of factors directly or indirectly depending on the year seasons. These fluctuations repeat regularly in one-year time and can be divided into two categories. The first type of seasonal fluctuations occurs in monthly, quarterly or half-year series and illustrates first of all an influence of year seasons and customs on economic activity. The second category of seasonal fluctuations are to be short-time oscillations that occur in one-month series. Their phases are presented within one day, twenty four hours, one week or one month. Main reasons for their occurrence are biological rhythm, customary division of labour, customs. ${ }^{3}$ In the majority of time series being subjects of economical analysis this type of fluctuations does not occur because examined series are available as monthly, quarterly, half-year or yearly data.

Irregular fluctuations result from indefinite chance causes that are not connected with the subject of the factor. Moreover, they are irregular when speaking both about their power and direction of activity. Main sources of these fluctuations are random events such as floods, draughts, earthquakes and political events such as wars and strikes.

Cyclical fluctuations are described as quite regularly repeated fluctuations, lasting more than one year and which are caused mainly by business cycle. Cyclical fluctuations result from economic factors, which makes difference between them and seasonal fluctuations.

Market of some goods, as well as the whole economy, fluctuate and mainly happen as consequences of business cycle. The same refers to property market ${ }^{4}$. In time series of variables describing property market it is also possible to find trend, seasonal fluctuations, irregular fluctuations and cyclical fluctuations.

These variables are the following: demand, supply and prices. Regarding prices on property market there can be: trend (in most cases trend is positive excluding Germany and Switzerland in 1975-2005 when real prices tended to decrease), seasonal fluctuations (increasing number of transactions during summer holidays), irregular fluctuations (decrease of flats' prices on flooded areas in Wrocław in 1997) and cyclical fluctuations resulting from economic factors that have an influence on behaviours of this market participants.

\section{Methodology of isolation of cyclical price fluctuations on the housing}

In this paper the methods of business cycles analysis were applied to house prices fluctuations on the local markets. Plurality of methods of business cycle measurement makes it difficult to determine the turning points and cycle phases. According to accepted procedure external image of the cycle, locations of turning points as well as the duration of phases will vary ${ }^{5}$.In this paper there have been imposed some methods of business cycle measurement that have their theoretical background in new classic macroeconomic concepts. According to R. E. Lucas ${ }^{6}$, business fluctuations are the set of moves around the trend determined by real

\footnotetext{
${ }^{2}$ Koniunktura gospodarcza Polski, Analiza grup produktowych, red. naukowy M. Rekowski, Wyd. AE w Poznaniu, Poznań 1997, p. 15.

${ }^{3}$ M. Lubiński, Analiza koniunktury i badanie rynków, Dom Wydawniczy Elipsa, Warszawa 2002, p. 42.

${ }^{4}$ H. Gawron, Opłacalność inwestowania na rynku nieruchomości, Wyd. AE w Poznaniu, Poznań 2008, p. 69.

${ }^{5}$ M. Lubiński, Analiza koniunktury i badania rynków, Dom Wydawniczy Elipsa, Warszawa 2002, p. 64.

${ }^{6}$ R. E. Lucas, Understanding Business Cycles, w Business Cycle Theory, red. F. E. Kydland, Edward Elgar
} 
GDP of the specific country. Such interpretation enables to measure the cycle as deviations from the trend. It is obvious that it refers only to business cycle. However, there are no obstacles to measure the subject of cyclical fluctuations for other economic variables identically. Then the trend will be searched within the series of variables other than GDP ${ }^{7}$.

Method of the cycle's measurement as deviations from the trend is used very often but it isn't the single one. Other basic methods of business cycle isolation are as follows: cycle of levels, cycle of growth, and cycle of deviations of growth rate from trend ${ }^{8}$. The first method abuts on estimations of fluctuations on the basis of absolute quantities of selected measuring instruments referring to the level of economic activity. The second method is based on growth dynamic. The last concept composes growth rates with long-time trend.

The first step to isolate cyclical fluctuations is to delete from the prime series seasonal and irregular fluctuations. The most popular and most often used methods of time series smoothing are X-12 ARIMA $^{9}$ and TRAMO-SEATS. The first method was worked out by the U.S. Bureau of the Census and the other one by V. Gomez and A. Maravall ${ }^{10}$. These tools join classic decomposition of time series to components connected with trend, seasoning and irregular factor with modeling of time series with the use of ARIMA models. Smoothing of time series by using these methods enables to eliminate seasonal fluctuations and irregular factors from the series.

In the concept of deviations from the trend an essentials element is the way of determining the trend itself because a course of received fluctuations of market conditions is conditioned by the trend. Identification of cyclical oscillations with the use of this method is doubtful because of arbitrary choice of its function which may have an influence on final results. It has to be pointed out that this problem is connected with deterministic trend only ${ }^{11}$.According to easiness of calculations and clear economic interpretation linear function is used most often. Using such deterministic trend amounts formally to finding the following equation:

$$
\xi_{t}=\alpha_{0}+\alpha_{1} * t+\varepsilon_{t}
$$

where:

$\hat{y}_{t}-$ theoretical trend values for variable $y$ in the time $t$,

$\alpha_{0}$ - estimator of parameter of trend's linear function defining a level of effects in the time $\mathrm{t}=0$,

$\alpha_{1}$ - estimator of parameter of trend's linear function defining an average increase of the value of effect in question,

$\varepsilon_{\mathrm{t}}$ - summand of remainder.

Assumption of linearity of trend's function causes that any element disturbing formation of real property prices is of short-time character. It is assumed, however, that after some time an influence of disturbing factor will be neutralized and prices return to permanent growth line resulting from long-time linear trend. The most important factor of long-time changes of real estate's prices are certainly changes in demand for property services. They depend mainly on economic situation of the economy thus tickling directly households -

\footnotetext{
Publishing Company, UK 1995, p. 85.

${ }^{7}$ M. Kruszka, Wyodrębnianie wahań cyklicznych, Warsztaty Makroekonometryczne, AE Poznań 2002, p.2.

${ }^{8}$ M. Lubiński, Analiza koniunktury i badania rynków, Dom Wydawniczy Elipsa, Warszawa 2002, pp. 64-69.

${ }^{9}$ D.F. Findley, B.C. Monsell, W.R. Bell, M.C. Otto i B. Chen, New Capabilities and Methods of the X-12 ARIMA Seasonal Adjustment Program, Journal of Business and Economic Statistics 1998, vol. 16, pp. 127-152.

${ }^{10}$ V. Gomez, A. Marvall, Programs TRAMO (Time series Regression with Arima noise, Missing observations, and Outliers) and SEATS (Signal Extraction in Arima Time Series). Instructions for the User, Banco de Espana, Working Paper 1996, nr 9628.

${ }^{11}$ M. Kruszka, Synchronizacja wahań koniunkturalnych $w$ gospodarce krajów rozwiniętych, Wiadomości Statystyczne 2003, nr 6, pp. 1-15.
} 
mainly their incomes and access to financing which is connected with mortgage loans rates.

If we use linear function to describe trend of prices on real estate market, $\alpha_{1}$ estimator informs about an average price increase. Considering the fact that GDP cannot be recognized as permanent changing rate process an assumption of linear trend to separate fluctuations of real flat prices would not be proper. Furthermore, negation of linear function as good approximation for trend of macroeconomic variables results also from formal statistical reasons. Nelson and Plosser ${ }^{12}$ made empirical investigations that demonstrated that in the dynamic of the majority of time series exists random walk with drift. Then the formal entry of such course is as follows:

$$
y_{t}=\mu+y_{t-1}+\varepsilon_{t} ;(2)
$$

where:

$\mathrm{y}_{\mathrm{t}}$ - empiric values $\mathrm{y}$ in the time $\mathrm{t}$,

$\varepsilon_{\mathrm{t}}-$ as in the equation,

$\mu$ - constant representing the $\operatorname{drift}(\mu>0)$.

Taking into consideration this element it can be stated that single disturbance of previous growth path will cause its permanent distortion. Acceptance of the thesis about formation of time series, as well as flats' prices $^{13}$, according to random walk with drift causes that the description of analyzed phenomenon with the use of linear trend is more and more complicated as it is changeable in time. It is more difficult to differentiate the trend from cyclical fluctuations as random walk causes that trend is also deviated ${ }^{14}$.Authors of the concept of real business cycle proposed statistical methods that can solve this problem. These methods are based on assumption that cyclical summand of variable y is a difference between its current value and a measure showing the value of the trend; the trend is weighted average of past, current and future observations ${ }^{15}$ :

$$
y_{t}^{c}=y_{t}-\tau_{t}-\sum_{j=-J}^{J} a_{j}^{*} y_{t-j} ;(3)
$$

where:

$\mathrm{y}^{\mathrm{c}}{ }_{\mathrm{t}}$ - cyclical summand of variable $\mathrm{y}$ in the time $\mathrm{t}$,

$\tau_{t}-$ stochastic (random) trend value.

This method, named the Hodrick-Prescott (HP) filter, allows calculating value $\tau_{\mathrm{t}}$, which minimize the expression:

$$
\sum_{t=1}^{T}\left(y_{t}-\tau_{t}\right)^{2}+\lambda \sum_{t=2}^{T-1}\left[\left(\tau_{t+1}-\tau_{t}\right)-\left(\tau_{t}-\tau_{t-1}\right)\right]^{2} ;(4)
$$

where:

$\lambda$ - smoothing parameter.

Smoothing parameter exposes various values depending on frequency of the phenomenon. If we have yearly data $\lambda=400$, for quarterly data $\lambda=1600$, and for monthly data $\lambda=14400^{16}$. The higher values of $\lambda$ parameter, the more "flat" is the whole trend. It follows that if $\lambda$ approaches infinity, using the filter we receive the same values as if we use linear

\footnotetext{
12 C.R. Nelson, C.I. Plosser, Trends and Random Walks in Macroeconomic Time Series; Some Evidence and Implications, Journal of Monetary Economics 1982, vol. 10, p. 139-162.

13 M.-C. Chen, Y. Kawaguchi, K. Patel, An Analysis of the Trends and Cyclical Behaviours of House Prices in the Asian Markets, Journal of Property Investment \& Finance 2004, vol. 22, nr 1, pp. 55-75.

${ }^{14}$ Wskaźniki wyprzedzające jako metoda prognozowania koniunktury w Polsce, red. nauk. M. Rekowski, Wyd. AE w Poznaniu, Poznań 2003r., pp. 100-101.

15 M. Kruszka, Synchronizacja wahań koniunkturalnych w gospodarce krajów rozwiniętych, Wiadomości Statystyczne 2003, nr 6, pp. 1-15.

${ }^{16}$ M.K. Evans, Practical Business Forecasting, Blackwell Publishing, Oxford 2003, p.v205.
} 
trend ${ }^{17}$. The most important limit of the presented filter is demanded minimal length of time serial that is being filtered. In practice minimal number of observations is 32 .

The serial received after using the HP filter shows long-time growth tendency of the variable that is not deterministic function but is being changed itself in time. In order to isolate cyclical fluctuations empiric values of the variable should be divided by estimations received by using the HP filter (and multiplied by 100); then we received the serial showed percentage fluctuations from the trend ${ }^{18}$.

\section{Data used in the research}

Flat prices indexes per square metre in Poznań were constructed with a mixadjustment method. From theoretical point of view the aim of this method is to define the pure change flat price. The data on asking prices used to construct flat price indexes were collected. As a result of methodological processes (repeated sales offers were omitted - this phenomenon of repeated offers was caused by reporting them to more than one agency.) the quantity of base data decreased half as much and amounted to 70000 in Poznan. The number of collected offers satisfies the condition of representative sample. In the chart 1 nominal and real flat prices indexes in Poznan in the years 1996-2008 are presented.

Nominal and real flat price indexes in Poznań in the years 1996-2008

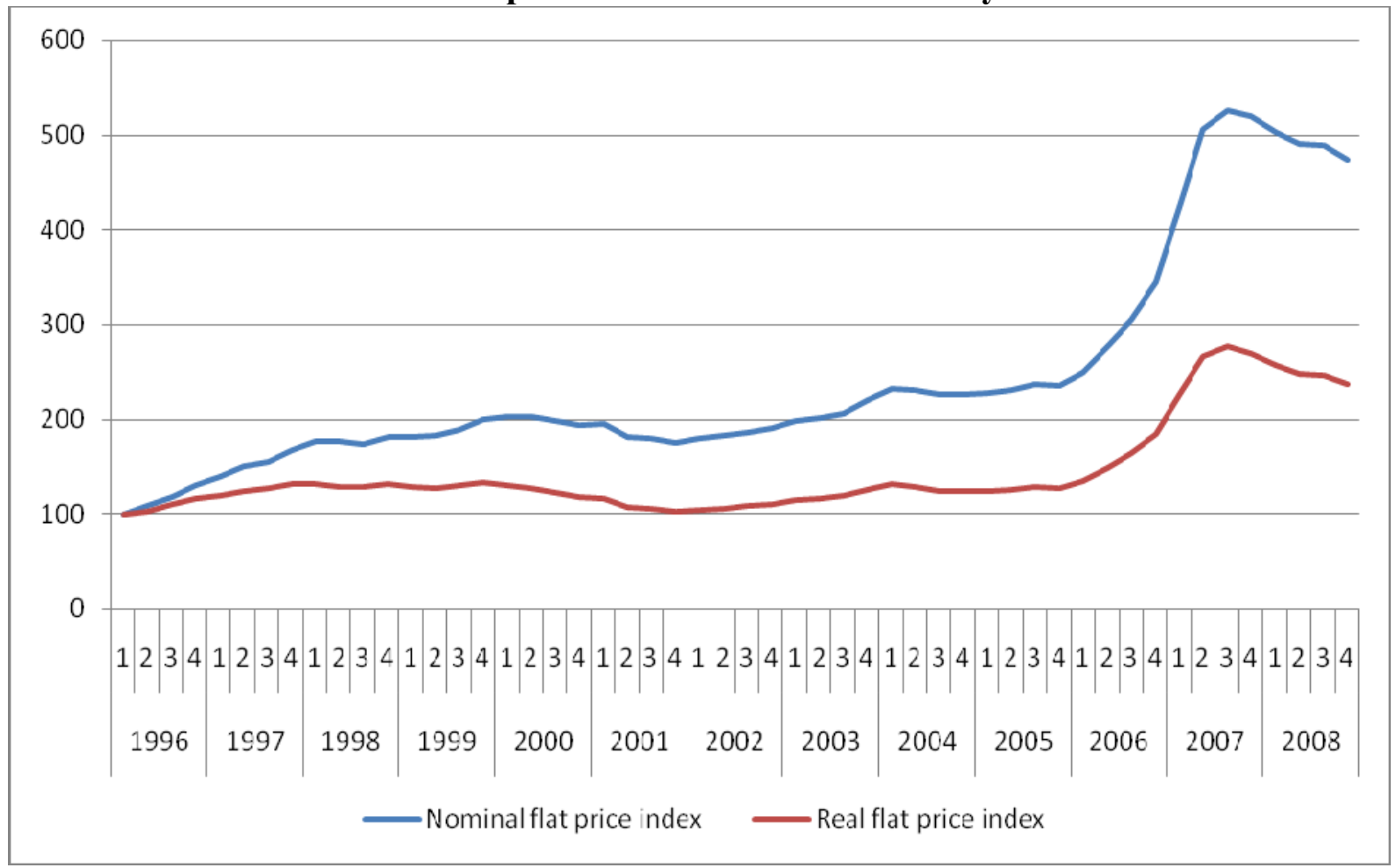

Source: Based on own calculations.

The analysis of chart 1 shows that nominal flat price indexes in Poznań increased by $370 \%$, during the years 1996-2008. It is worth noticing that real flat price indexes in Poznan

17 T. Cogley, J.M. Nason, Effects of the Hodrick-Prescott Filter on Trend and Difference Stationary Time Series: Implications for Business Cycle Research, Journal of Economic Dynamics and Control 1995, vol. 19, pp. $253-278$.

${ }^{18}$ In the situation when variables (free of seasoned fluctuations and any other chances) are logarithmed, in order to isolate cyclical fluctuations we should subtract empiric values of the variable by estimation resulted from use of the HP filter and multiply by 100 . 
increased by $140 \%$. In both cities particularly rapid growth took place in the year 2006 . According to prof. Bryx ${ }^{19}$ the rapid growth resulted from two factors. Firstly, the market was informed about the possibility of increasing V.A.T. (value addend tax) by $22 \%$. Thus only those flats that were built just at that moment were burdened with 7\% V.A.T. Secondly, the other important information was that the year 2006 was the last year to use tax relief. Taking into consideration the above mentioned facts it seems that rapid growth of demand met fixed supply and resulted in huge flat price growth in the year 2006.

\section{Fluctuations of flat' prices on housing markets in Poznań}

Cyclical fluctuations of flat prices on the real estate market in Poznan were determined as deviations from the stochastic (random) trend. The very first step in the process of determination of the fluctuation was to make real (for the first quarter of 1996) flat price indexes in the years1996-2008. Then the serial of real prices of $1 \mathrm{~m}^{2}$ of flat was decomposed into the following components:

$\square$ seasonal fluctuations,

$\square$ irregular fluctuations,

fluctuations of both trend and cyclical,

$\square$ stochastic (random) trend.

Firstly, seasonal and irregular fluctuations were eliminated using X-12 ARIMA procedure. Basing on the final curve of fluctuations of both trend and cyclical (Henderson curve) there was estimated stochastic trend (with the use of the HP filter). It was the last stage of decomposition of analysed serial that enabled to determine cyclical fluctuations. The serial presenting cyclical fluctuations measured as a deviation cycle was determined by dividing the value of fluctuation of both trend and cyclical by proper values generated by the HP filter. Such serial was multiplied by $100 \%$ to receive percentage deviations from the trend curve. Diagram 2 presents cyclical fluctuations of real flat prices index in Poznań in 1996-2008.

Chart 2

Cyclical fluctuations of real flat price index in Poznań in the years 1996-2008

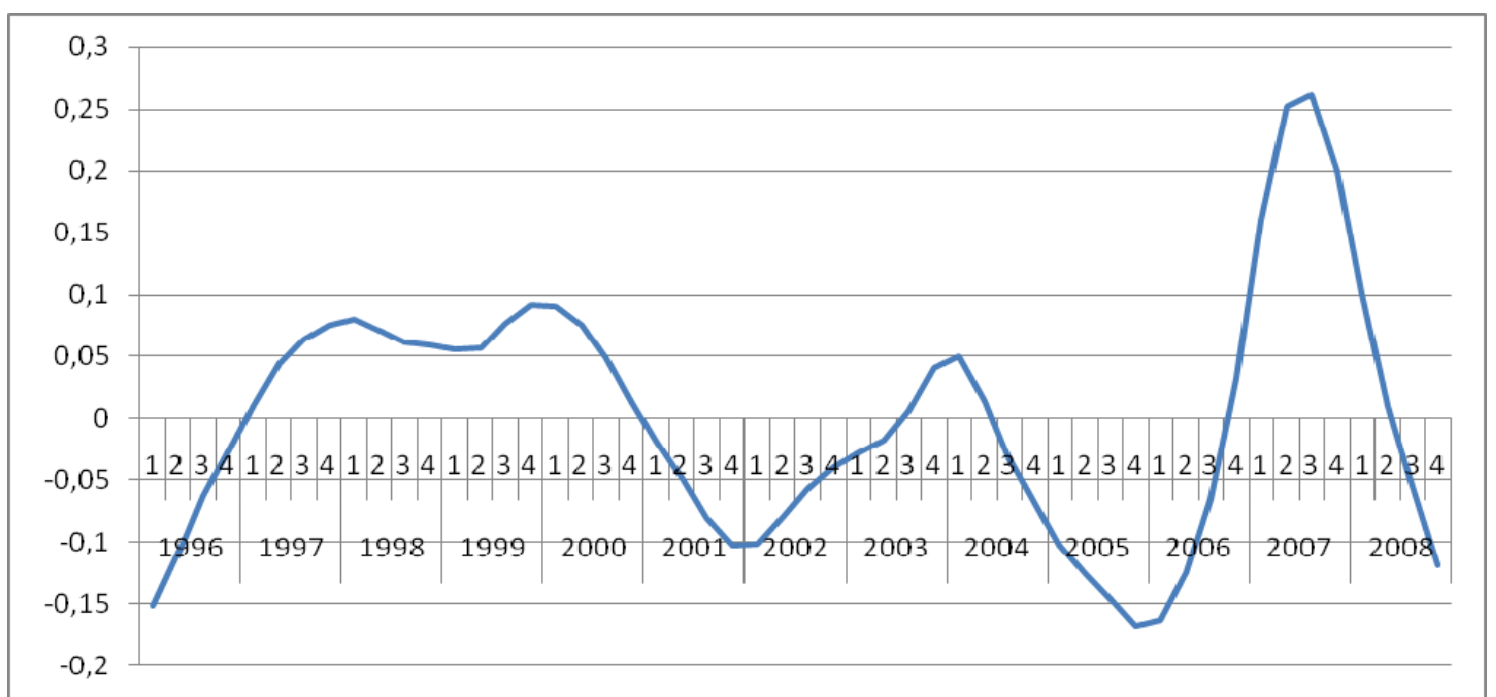

Source: Based on own calculations.

19 M. Bryx, Prawo do dachu nad głową, Problemy rozwoju miast 2007 nr 4, Instytut Rozwoju Miast, Kraków 2007 
Fluctuations mentioned above were the basis for further analyses. The aim was to determine morphologic attributes of these fluctuations. It was assumed in the analysis that the upper (lower) turning point appears in the period when the value of the analyzed indicator reaches its maximum (minimum). After establishing the turning points it was possible to differentiate the phases of the business cycles.

Therefore, each cycle consists of an increase phase (between the lower and upper turning point) and a decrease phase (between the upper and lower turning point).Restrictions were imposed to ensure that the periods of increases and decreases had a minimum length of six quarters in order to avoid spurious cycles ${ }^{20}$. Table 1 presents morphologic cyclical fluctuations of prices of 1 sq.m of flat attributes in Poznań in 1996-2008.

Morphologic cyclical fluctuations of prices of $1 \mathrm{~m}^{2}$ of flat in Poznań in 1996-2008

Table 1

\begin{tabular}{|c|c|c|c|c|c|c|}
\hline \multirow{4}{*}{$\begin{array}{c}\text { Attributes of } \\
\text { cycle }\end{array}$} & \multicolumn{6}{|c|}{ Phases of cyclical fluctuations } \\
\hline & increasing & decreasing & increasing & decreasing & increasing & decreasing \\
\hline & \multicolumn{6}{|c|}{ Within the time } \\
\hline & up to IV 1999 & $\begin{array}{c}\text { I 2000-IV } \\
2001\end{array}$ & $\begin{array}{c}\text { I } 2002-\text { I } \\
2004\end{array}$ & $\begin{array}{c}\text { II } 2004 \text { - IV } \\
2005 \\
\end{array}$ & $\begin{array}{c}\text { I 2006- III } \\
2007 \\
\end{array}$ & IV 2007 - \\
\hline \multicolumn{7}{|c|}{ Length in quarters } \\
\hline phases & $\min .16$ & 8 & 9 & 7 & 7 & $\min .5$ \\
\hline cycle & \multicolumn{2}{|c|}{$\min .24$} & \multicolumn{2}{|c|}{16} & \multicolumn{2}{|c|}{$\min .13$} \\
\hline
\end{tabular}

Source: Based on own calculations.

In 1996 -2008 on the secondary housing market in Poznań it was possible to observe only two increasing and decreasing phase. The beginning of increasing phase (it ends in the fourth quarter of 1999) cannot be specified because cyclical fluctuations of prices of 1 sq.m of flat before 1996 are unknown and in the time from the first quarter of 1996 up to the fourth quarter of 1999 the bottom turning point was not found. It can only be assumed, however, that increasing phase lasted minimum 16 quarters and cycle of flat prices on the real estate market in Poznan - that ended in the fourth quarter of 2001 - lasted minimum 24 quarters. In the first quarter of 2002 the next increasing phase began that ended in the first quarter of 2004. After that two phases can be distinguished that lasted 7 quarters each (one decreasing and one increasing). In the fourth quarter of 2007 next decreasing phase begun.

\section{REFERENCES}

1. C.R. Nelson, C.I. Plosser, Trends and Random Walks in Macroeconomic Time Series; Some Evidence and Implications, Journal of Monetary Economics 1982, vol. 10

2. D.F. Findley, B.C. Monsell, W.R. Bell, M.C. Otto i B. Chen, New Capabilities and Methods of the X-12 ARIMA Seasonal Adjustment Program, Journal of Business and Economic Statistics 1998, vol. 16

3. H. Gawron, Opłacalność inwestowania na rynku nieruchomości, Wyd. AE w Poznaniu, Poznań 2008

4. Koniunktura gospodarcza Polski, Analiza grup produktowych, red. naukowy M. Rekowski, Wyd. AE w Poznaniu, Poznań 1997

\footnotetext{
${ }^{20}$ N. Girouard, M. Kennedy, P. van den Noord, Ch. André, Recent House Price Developments: The Role of Fundamentals, Economics Department Working Papers No. 475, rok 2008, p. 195.
} 
5. M. Bryx, Prawo do dachu nad głowa, Problemy rozwoju miast $2007 \mathrm{nr}$ 4, Instytut Rozwoju Miast, Kraków 2007

6. M. Kruszka, Synchronizacja wahań koniunkturalnych $w$ gospodarce krajów rozwiniętych, Wiadomości Statystyczne 2003, nr 6

7. M. Kruszka, Wyodrębnianie wahań cyklicznych, Warsztaty Makroekonometryczne, AE Poznań 2002

8. M. Lubiński, Analiza koniunktury i badania rynków, Dom Wydawniczy Elipsa, Warszawa 2002

9. M.-C. Chen, Y. Kawaguchi, K. Patel, An Analysis of the Trends and Cyclical Behaviours of House Prices in the Asian Markets, Journal of Property Investment \& Finance 2004, vol. 22, nr 1

10. M.K. Evans, Practical Business Forecasting, Blackwell Publishing, Oxford 2003

11. N. Girouard, M. Kennedy, P. van den Noord, Ch. André, Recent House Price Developments: The Role of Fundamentals, Economics Department Working Papers No. 475, rok 2008

12. R. E. Lucas, Understanding Business Cycles, w Business Cycle Theory, red. F. E. Kydland, Edward Elgar Publishing Company, UK 1995

13. T. Cogley, J.M. Nason, Effects of the Hodrick-Prescott Filter on Trend and Difference Stationary Time Series: Implications for Business Cycle Research, Journal of Economic Dynamics and Control 1995, vol. 19

14. V. Gomez, A. Marvall, Programs TRAMO (Time series Regression with Arima noise, Missing observations, and Outliers) and SEATS (Signal Extraction in Arima Time Series). Instructions for the User, Banco de Espana, Working Paper 1996, nr 9628.

15. Wskaźniki wyprzedzajace jako metoda prognozowania koniunktury $w$ Polsce, red. nauk. M. Rekowski, Wyd. AE w Poznaniu, Poznań 2003r. 